\title{
Plasma lipid profile of mice fed diet supplemented with broiler fat
}

\author{
GB Das ${ }^{1}$, ME Hossain* ${ }^{1}$, MA Akbar ${ }^{2}$
}

${ }^{1}$ Department of Animal Science and Nutrition, Faculty of Veterinary Medicine, Chittagong Veterinary and Animal Sciences University, Khulshi, Chittagong 4225; '²epartment of Animal Nutrition, Faculty of Animal Husbandry,

Bangladesh Agricultural University, Mymensingh 2202, Bangladesh

\begin{abstract}
This study was conducted with 180 female Swiss albino mice to examine the effects of supplementing broiler fat in the diets of mice on blood lipid profile. Twenty one days old mice were collected from ICDDRB, Mohakhali, Dhaka. They were randomly distributed in four groups having three replications each. Each replicate group had 15 mice. Results revealed that supplementation of broiler fat in mice diet significantly changed $(p<0.05)$ triglyceride $(T G)$ and low density lipoprotein $(L D L)$ among groups. The control group $\left(\mathrm{T}_{0}\right)$ had the highest level of cholesterol and LDL. Cholesterol, TG and LDL markedly increased $(p<0.05)$ in all dietary treatment groups, while high density lipoprotein (HDL) significantly $(p<0.01)$ decreased after supplementation of experimental diets. It was concluded that all the dietary treatments in general increased blood cholesterol, TG and LDL in mice fed broiler fat with different oil supplements. However, the soybean and palm oil group was comparatively better than other groups in respect of cholesterol, HDL and LDL at the blood lipid profile of mice. Therefore, it can be concluded that consumption of broiler fat with soybean and palm oil could be less harmful for mice.
\end{abstract}

Key words: Cholesterol, HDL, LDL, mice, triglyceride

Bangladesh Animal Husbandry Association. All rights reserved.

Bang. J. Anim. Sci. 2014. 43 (1): 21-24

\section{Introduction}

Currently, people are more concerned than before regarding the relationship between animal fat and coronary heart disease. It is well established that animal fat contains higher amounts of saturated fats rich in LDL than vegetable oils. Most of the saturated fats are deposited in the abdomen of broilers. Therefore, consumption of broiler meat containing fat in usual diet could raise the level of LDLs in human blood that may lead to coronary diseases. These saturated fats build up of cholesterol particularly LDL in the artery walls. As a result, the arteries become narrow and hardened, their elasticity disappears and it becomes difficult for blood to flow properly. This condition is known as atherosclerosis. Atherosclerosis can cause heart attack if it completely blocks the blood flow in the coronary arteries. It can cause a stroke if it completely blocks the brain (carotid) arteries. Atherosclerosis can also occur in the arteries of the neck, kidneys, thighs and arms causing partial or complete disfunctioning of those organs ( Ma et al. 1995; Mente et al. 2009 and German et al. 2004). So it is important to find out the level of blood cholesterol, LDL, HDL and TG in human blood fed broilers fat that were fed diets supplemented with soybean oil, palm oil and fish oil. Testing the lipid profile of mice fed diet supplemented with above oils could be a good indicator to predict whether composition of broiler fat is influenced by different oil sources and their subsequent effect on human health. Therefore, the current study was undertaken to examine the effects of adding broiler fat to the diets of mice and its subsequent effects on lipid profile.

\section{Materials and methods}

This experiment was conducted at the animal nutrition laboratory of Chittagong Veterinary and Animal Sciences University, Chittagong. A total of 180 female Swiss albino mice aged 21 days were collected from ICDDRB, Mohakhali, Dhaka. They were randomly distributed in four groups having three replications. Each replication had 15 mice. The duration of experiment was 60 days. Fifteen Swiss albino mice were reared in each cage measuring about 18" (length) x 10" (width) x 7" (height). Wood shavings were used as litter and these were changed every alternate day. Mice were restrained as and when required by holding two thirds of the tail with one hand placing on 


\section{Plasma lipid profile of mice fed broiler fat}

wire net and grasping the skin. The abdominal fats were collected after harvesting broilers from the experiment fed different oil sources. For collection of abdominal fats three hundred ( 35 days of old) broilers were slaughtered. After collection of abdominal fats from each treatment these fats were heated for the preparation of oil. Four diets $T_{0}, T_{1}, T_{2}$, and $T_{3}$ were formulated using locally available feed ingredients where $T_{1}$ was fortified with broilers fat fed $2.5 \%$ soybean oil, $\mathrm{T}_{2}$ with broilers fat fed $2.5 \%$ palm oil, $\mathrm{T}_{3}$ with broilers fat fed $2.5 \%$ marine fish oil and $T_{0}$ was the control.

Table 1. Composition of diets

\begin{tabular}{|c|c|c|c|c|}
\hline \multirow[t]{2}{*}{ Ingredient (\%) } & \multicolumn{4}{|c|}{ Dietary treatments 3} \\
\hline & $\mathrm{T}_{0}$ & $\mathrm{~T}_{1}$ & $\mathrm{~T}_{2}$ & $\mathrm{~T}_{3}$ \\
\hline Maize & 12.21 & 9.71 & 9.71 & 9.71 \\
\hline Wheat & 27.0 & 27.0 & 27.0 & 27.0 \\
\hline Wheat bran & 17.0 & 17.0 & 17.0 & 17.0 \\
\hline Rice polish & 6.0 & 6.0 & 6.0 & 6.0 \\
\hline Til oil cake & 12.0 & 12.0 & 12.0 & 12.0 \\
\hline Protein concentrate ${ }^{1}$ & 10.0 & 10.0 & 10.0 & 10.0 \\
\hline Skim milk & 1.0 & 1.0 & 1.0 & 1.0 \\
\hline Soybean meal & 5.0 & 5.0 & 5.0 & 5.0 \\
\hline Bengal gram & 8.0 & 8.0 & 8.0 & 8.0 \\
\hline Salkill & 0.4 & 0.4 & 0.4 & 0.4 \\
\hline Lime stone ${ }^{2}$ & 0.5 & 0.5 & 0.5 & 0.5 \\
\hline Feed zyme & 0.05 & 0.05 & 0.05 & 0.05 \\
\hline Choline chloride & 0.01 & 0.01 & 0.01 & 0.01 \\
\hline Sorbatox & 0.03 & 0.03 & 0.03 & 0.03 \\
\hline Antioxidant & 0.05 & 0.05 & 0.05 & 0.05 \\
\hline Common salt & 0.5 & 0.5 & 0.5 & 0.5 \\
\hline Abdominal fat of broiler & - & 2.5 & - & - \\
\hline Abdominal fat of broiler & - & - & 2.5 & - \\
\hline Abdominal fat of broiler & - & - & - & 2.5 \\
\hline Calculated values & & & & \\
\hline ME (kcal/kg) & 2512 & 2644 & 2644 & 2644 \\
\hline CP (g/100g) & 23.72 & 23.49 & 23.49 & 23.49 \\
\hline
\end{tabular}

${ }^{1} \mathrm{CP}=60 \%, \quad \mathrm{CF}=3.0 \%, \quad \mathrm{EE}=13.0 \%, \quad \mathrm{Ash}=24.0 \%$, $\mathrm{Ca}=6.5 \%, \quad \mathrm{P}=2.5 \%$, Lysine $=7.0 \%$, Methionine $=$ $2.0 \% ;{ }^{2} \mathrm{DM}=98.9 \%, \mathrm{Ca}=35.8 \%, \mathrm{P}=0.02 \% ;{ }^{3} \mathrm{~T}_{0}$, diet without broiler fat; $\mathrm{T}_{1}$, diet with broiler fat of broiler fed $2.5 \%$ soybean oil; $\mathrm{T}_{2}$, diet with broiler fat of broilers fed $2.5 \%$ Palm oil; $T_{3}$, diet with broiler fat of broilers fed $2.5 \%$ fish oil

The diets were randomly supplied to four groups of birds. Food and water was supplied every day after completing the routine cleaning of cages. Pellet feed $(5 \mathrm{~g})$ was supplied per day and 4-5 ml of water was provided in water bottle. Blood Cholesterol, LDL, HDL and TG of mice were estimated during the experimental period. Total blood was collected through cardiac puncture. This was done before and after completion of the experiment. Blood samples were centrifuged and serum was separated. The serum samples were kept at $-5 \circ \mathrm{C}$ until cholesterol analysis. Serum samples were analyzed for blood lipid profile according to the colorimetric method of Abell et al. (1952). The analytical work was done in the diagnostic laboratory of Chittagong Metropolitan Hospital (PVT) Ltd, 698/752 OR Nizam Road, Chittagong, Bangladesh. The data were analyzed for analysis of variance in a CRD using SPSS (2007) and Stata (2009). Plasma lipid profiles of mice before and after feeding experimental diets were analyzed by using Chi-square test. Means showing significant differences were compared by Duncan's New Multiple Range Test (Duncan 1955).

\section{Results and discussion}

The cholesterol, TG, HDL and LDL level of mice before feeding broiler fat are presented in Table 2. The effects of broiler fat on cholesterol, TG, HDL and LDL of different groups of mice is shown in Table 3. There was no significant difference in cholesterol level among the different groups of mice. However the animals of groups $T_{0}$ and $T_{3}$ showed slightly higher cholesterol than that of the other two groups. Unlike cholesterol, TG level of different groups of mice differed $(p<0.01)$ due to feeding of different diets. In terms of TGs, mice receiving $\mathrm{T}_{2}\left(2.5 \%\right.$ palm oil) and $\mathrm{T}_{3}(2.5 \%$ fish oil) had higher values than that of others. On the other hand, HDL level among the different groups of mice did not differ $(p>0.05)$. The control group $\left(T_{0}\right)$ showed $(p<0.01)$ higher level of LDL than those of other treatment groups. The differences in lipid profile between before and after feeding experiment of mice are shown in Table 4. The data in the Table showed that in case of cholesterol level differed significantly $(p<0.05)$ before and after feeding of experimental diet. In case of TG, the mean values were higher in after experiment group than that of the before experimental groups of treatment. On the other hand, means values of HDL level obtained before experiment decreased significantly $(p<0.01)$ in comparison with after experiment irrespective of dietary treatment groups. Similarly, in case of LDL, it increased significantly $(p<0.01)$ higher than that of the before experimental groups. 
Das et al. (2014) Bang. J. Anim. Sci. 43 (1): 21 - 24

Table 2. Blood lipid profile of mice before supplementation of the diet

\begin{tabular}{lllllll}
\hline $\begin{array}{l}\text { Parameter } \\
\text { (mg/dl/mouse) }\end{array}$ & \multicolumn{4}{c}{ Dietary treatments } & SEM & Sig. \\
\cline { 2 - 5 } & $\mathrm{T}_{0}$ & $\mathrm{~T}_{1}$ & $\mathrm{~T}_{2}$ & $\mathrm{~T}_{3}$ & & \\
\hline Cholesterol & 140.33 & 138.67 & 141.33 & 145.65 & 2.03 & $\mathrm{NS}$ \\
TG & 240.67 & 206.67 & 253.33 & 273.67 & 12.8 & $\mathrm{NS}$ \\
$\mathrm{HDL}$ & 70.33 & 74.33 & 75.33 & 75.33 & 1.68 & $\mathrm{NS}$ \\
LDL & 23.33 & 20.00 & 19.67 & 20.33 & 1.62 & $\mathrm{NS}$ \\
\hline
\end{tabular}

$T_{0}$, diet without broiler fat; $T_{1}$, diet with broiler fat of broiler fed $2.5 \%$ soybean oil; $\mathrm{T}_{2}$, diet with broiler fat of broilers fed $2.5 \%$ Palm oil; $T_{3}$, diet with broiler fat of broilers fed $2.5 \%$ fish oil

Non-significant differences in the blood lipid profile of the mice before starting the experiment indicates that there were similar levels of four components of the profile, except there were slightly higher TG level in mice of $T_{2}$ and $T_{3}$. Nonsignificant differences between different treatment means in respect of cholesterol indicate that different sources of oil had no influence on blood cholesterol level of mice. Significant difference among treatments in TG levels of mice in $T_{2}$ fed palm oil related fat and $T_{3}$ fed fish oil related fat and significantly higher level of TG compared to those of $T_{0}$ and $T_{1}$ were found. The reason for increased level of $T G$ in $T_{2}$ and $T_{3}$ compared to other treatments is unknown but part could be due to already higher level of TG in these two treatment groups before starting the experiment (Table 2 ).

Table 3. Blood lipid profile of mice after supplementation of the diet

\begin{tabular}{lllllll}
\hline $\begin{array}{l}\text { Parameter } \\
\text { (mg/d/mouse) }\end{array}$ & \multicolumn{4}{c}{ Dietary treatments ${ }^{1}$} & \multicolumn{1}{c}{ SEM } & Sig. \\
\cline { 2 - 5 } & $\mathrm{T}_{0}$ & \multicolumn{1}{c}{$\mathrm{T}_{1}$} & \multicolumn{1}{c}{$\mathrm{T}_{2}$} & \multicolumn{1}{c}{$\mathrm{T}_{3}$} & & \\
\hline Cholesterol & 159.00 & 149.67 & 139.67 & 153.67 & 2.77 & $\mathrm{NS}$ \\
$\mathrm{TG}$ & $290.67^{\mathrm{b}}$ & $299.33^{\mathrm{b}}$ & $345.00^{\mathrm{a}}$ & $340.33^{\mathrm{a}}$ & 7.56 & $* *$ \\
$\mathrm{HDL}$ & 36.33 & 42.67 & 32.67 & 34.33 & 1.47 & $\mathrm{NS}$ \\
$\mathrm{LDL}$ & $81.00^{\mathrm{a}}$ & $51.33^{\mathrm{b}}$ & $44.67^{\mathrm{b}}$ & $55.00^{\mathrm{b}}$ & 4.50 & ** \\
\hline
\end{tabular}

${ }^{1} T_{0}$, diet without broiler fat; $T_{1}$, diet with broiler fat of broiler fed $2.5 \%$ soybean oil; $\mathrm{T}_{2}$, diet with broiler fat of broilers fed $2.5 \%$ Palm oil; $\mathrm{T}_{3}$, diet with broiler fat of broilers fed $2.5 \%$ fish oil

There were no significant differences between different treatment means in respect of $\mathrm{HDL}$ indicate that different source of oil had no significant influence on HDL level of blood. It is evident from the value of LDL content in the lipids of mice after experiment that feeding fat of different sources to mice resulted in significantly lower LDL levels in $T_{2}$ group receiving palm oil fat.
Table 4. Blood lipid profile of mice before and after supplementation of the diet

\begin{tabular}{|c|c|c|c|c|c|}
\hline \multicolumn{2}{|c|}{ Treatment groups } & \multicolumn{4}{|c|}{ Parameters (mg/dl/mouse) } \\
\hline & & Cholesterol & TG & $\mathrm{HDL}$ & $\overline{L D L}$ \\
\hline \multirow[t]{4}{*}{$\overline{T_{0}}$} & Before & 140.33 & 240.67 & 70.33 & 23.33 \\
\hline & After & 159.00 & 290.67 & 36.33 & 81.00 \\
\hline & SEM & 3.18 & 2.65 & 0.58 & 4.26 \\
\hline & Significance & * & ** & ** & ** \\
\hline \multirow{4}{*}{$\mathrm{T}_{1}$} & Before & 138.67 & 206.67 & 74.33 & 20.00 \\
\hline & After & 149.67 & 299.33 & 42.67 & 51.33 \\
\hline & SEM & 2.00 & 3.7 & 4.37 & 2.33 \\
\hline & Significance & * & ** & * & ** \\
\hline \multirow{4}{*}{$\mathrm{T}_{2}$} & Before & 141.33 & 253.33 & 75.33 & 19.67 \\
\hline & After & 139.67 & 345.00 & 32.67 & 44.67 \\
\hline & SEM & 7.45 & 10.93 & 1.76 & 1.53 \\
\hline & Significance & NS & * & ** & ** \\
\hline \multirow{4}{*}{$\mathrm{T}_{3}$} & Before & 145.67 & 273.33 & 75.33 & 20.33 \\
\hline & After & 153.67 & 340.33 & 34.33 & 55.00 \\
\hline & SEM & 4.73 & 10.50 & 4.00 & 2.96 \\
\hline & Significance & NS & * & ** & ** \\
\hline
\end{tabular}

$T_{0}$, diet without broiler fat; $T_{1}$, diet with broiler fat of broiler fed $2.5 \%$ soybean oil; $\mathrm{T}_{2}$, diet with broiler fat of broilers fed $2.5 \%$ Palm oil; $\mathrm{T}_{3}$, diet with broiler fat of broilers fed $2.5 \%$ fish oil

It is better to have higher level of HDL and lower level of LDL in the blood. From this point of view $\mathrm{T}_{1}$ group of mice had higher $\mathrm{HDL}$ and second lowest LDL content and seems to be better than other treatment groups. Although LDL level (44.67 mg/dl) of $T_{2}$ group was the lowest of all which was a good sign, but HDL level (32.67 $\mathrm{mg} / \mathrm{dl}$ ) was the lowest and TG $(345.00 \mathrm{mg} / \mathrm{dl})$ was the highest. It was difficult to rank it as the better source of fat for mice. There was a variation in respect of cholesterol level of mice due to feeding different diets supplemented with fat of different sources which ranged from 1.66 to 18.67. It was interesting to note that the variation in $T_{2}$ group was the lowest (1.66). Feeding broilers fat increased the cholesterol level of mice in all groups of mice except in $T_{2}$ that received palm oil fat which slightly decreased giving beneficial effect of this fat on mice health. The significant increase of TG in $T_{2}(18.69 \%)$ and $\mathrm{T}_{3}(17.08 \%)$ groups of mice indicated that feeding fats of palm oil and fish oil resulted in increased TG level in the blood of mice to a greater extent than that of soybean oil and control. The highest increase $(30.61 \%)$ in the level of $\mathrm{HDL}$ of $\mathrm{T}_{1}$ group indicates the better influence of soybean oil on mice health since it is 
better to have increased level of HDL in the blood of mice. Fish oil fed group $\left(\mathrm{T}_{3}\right)$ was in the second position from this point of view. However, increase of LDL level was the highest in control group $(81.00 \%)$ and the lowest in $T_{2}$ group of mice fed palm oil. This indicates the better effect of palm oil and soybean oil on mice health.

\section{Conclusion}

It can be concluded that dietary treatments increased blood cholesterol, TG and LDL in mice after feeding the broilers fat and different oils. However, the soybean and palm oil groups are comparatively better than other group for the production of cholesterol, HDL and LDL in blood lipid profile of mice. Therefore, it can be concluded that the soybean and palm oil supplemented broilers fat may be less harmful for mice. However, further work on human health would be beneficial.

\section{References}

Abell LL, Levy BB, Brodie BB, Kendall FE (1952). A simplified method for the estimation of total cholesterol in serum and demonstration of its specificity. Journal of Biological Chemistry, 195: 357- 366.

Duncan DB (1955). Multiple range and multiple ' $F$ ' test. Biometrics, 11: 1-42.

German J, Bruce Dillard Cora J (2004). Saturated fats: what dietary intake?. American Journal of Clinical Nutrition, 80: 550-559.

Ma J, Folsom AR, Shahar E, Eckfeldt JH (1995). Plasma fatty acid composition as an indicator of habitual dietary fat intake in middle-aged adults. The Atherosclerosis Risk in Communities (ARIC) Study Investigators. American Journal of Clinical Nutrition, 62: 564-671.

Mente A, De Koning L, Shannon HS, Anand SS (2009). A systematic review of the evidence supporting a causal link between dietary factors and coronary heart disease. Archives of Internal Medicine, 169, 659-669.

SPSS (2007). SPSS for Windows, Version 16.0,SPSS Inc, Chicago.

Stata (2009). Stata Statistical Software, Version 11C, TX: StataCorp LP, College Station, USA. 